\title{
UC pursues rooted research with a nonprofit, links the many benefits of community gardens
}

\author{
A study of eight San Diego County community gardens demonstrates their role in gardeners' \\ health and well-being and community development.
}

by Mirle Rabinowitz Bussell, James Bliesner and Keith Pezzoli

$\mathrm{T}$ informal economy, healthy food options and alternative urban food systems are interconnected in important ways. To better understand these connections, we analyzed the production, distribution and consumption of urban agricultural products in several low-income San Diego neighborhoods with a focus on community gardens.

Community gardens play a critical role in alternative food systems since they typically operate in socially disadvantaged areas and serve to enhance the economic, social and nutritional needs of local residents. Integrating knowledge about food systems, health and ecology with knowledge about labor force dynamics and grassroots community development creates actionable theory suggesting new pathways for jointly improving social and economic conditions in the context of urban food systems. In this paper, we define the informal economy as economic transactions that are not regulated by the state and are primarily completed through cash transactions (Castells and Portes 1989; Hart 1973).

\section{Abstract}

The informal economy, healthy food options and alternative urban food systems are interconnected in important ways. To better understand these connections, and explore a rooted university approach to working with communities, we collaborated with the San Diego Community Garden Network to analyze the production, distribution and consumption of produce from eight community gardens in San Diego County. The project engaged UC San Diego researchers and students with county residents and community-based organizations to develop a survey together. Interviews with the gardeners and data from the completed survey document the ways in which community gardens contribute to individual and household health, well-being and community development. They suggest that despite perceptions that community gardens have marginal commercial capacity, they have the potential to contribute in meaningful ways to community development, particularly in low-income neighborhoods.

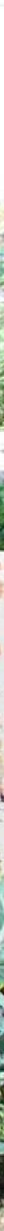


Our research project further enhanced our understanding of the merits of the "rooted university," a university that invests a significant amount of its attention and resources in place-based education, integrative research and community engagement. It engaged university researchers with residents and community organizations in a place-based (rooted), mutually beneficial exploration seeking ways to link community gardens, grassroots community development and access to healthy food. Following Ferguson and Dickens (1999), we define community development as a place-based comprehensive effort that produces assets in five forms: physical, social, intellectual/human capital, political and financial.

With funding from the UC Global Food Initiative and in collaboration with the San Diego Community Garden Network, we administered a survey to 120 community gardeners at eight gardens throughout San Diego County. Undergraduate students in the Urban Studies and Planning Program at UC San Diego helped design and conduct the survey as part of a field research practicum course created expressly for this project.

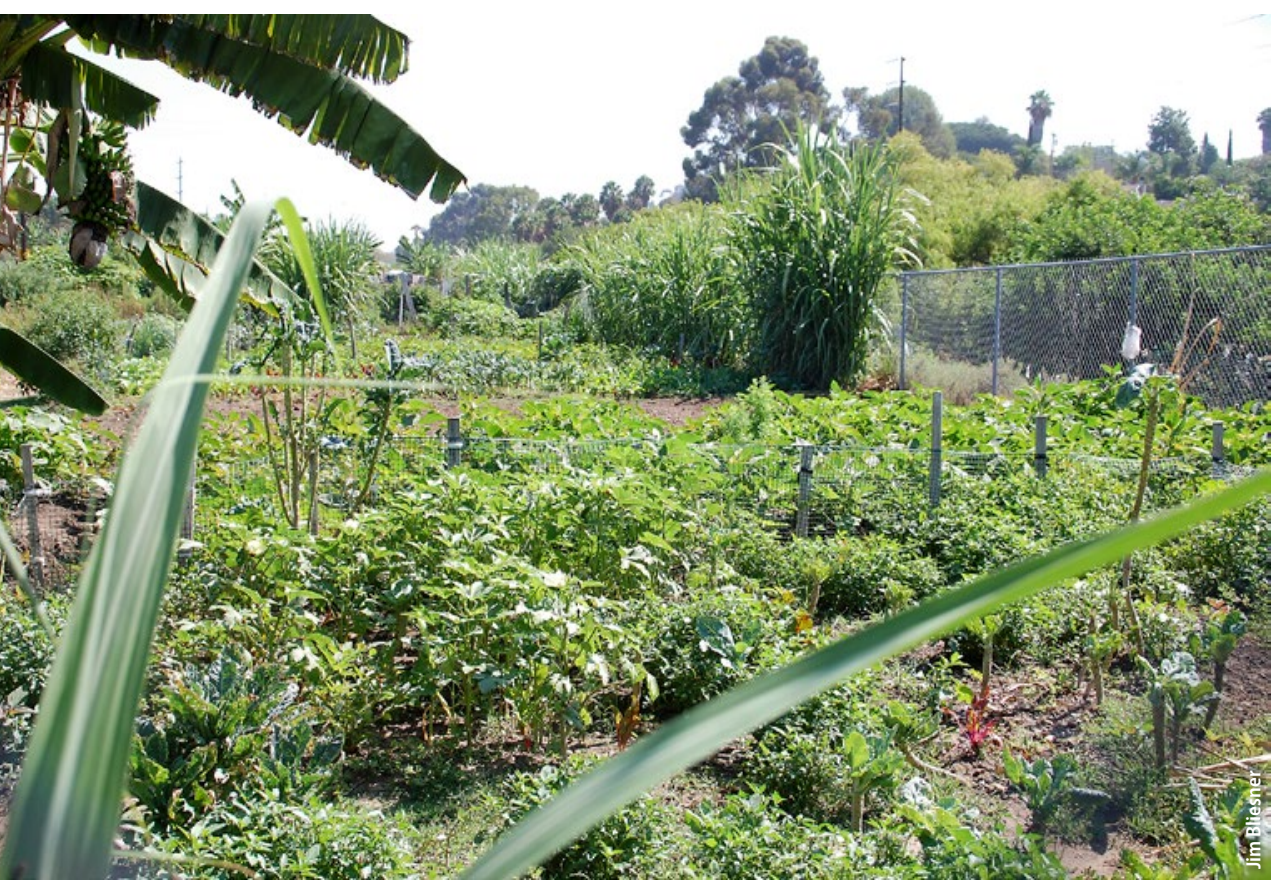

The New Roots Fresh Farm Community Garden, in El Cajon, provides garden plots to new refugees, who use them for small business farming.

\section{Urban food systems}

In understanding how food gets from farm to table, it is critical that both formal and alternative urban food systems are clearly outlined and their relationship to one another acknowledged. The academic literature on urban agriculture is rapidly expanding (Golden 2013) and informed our research. Studies have identified the complexity and hybridity that exist in local food supply chain relationships between producers, processors, distributors and retailers in both alternative and formal systems (Mount 2010).
According to a University of Missouri urban agriculture report, a food system includes the following eight components: growing, harvesting, processing, packaging, distributing, marketing, consuming and disposing of food (Hendrickson and Porth 2012). When these components are integrated to benefit the environmental, economic, social and nutritional health of a specific geographic area, an alternative community food system is formed (Garrett and Feenstra 1999). This framework of an alternative community food system is often used interchangeably with the concepts of informal, local or regional food systems; scholars have found the boundaries between them difficult to delineate. For example, while the congressional definition of "local" is "less than 400 miles from its origin" (Hendrickson and Porth 2012; Hicks and Seidl 2008), these geographic constraints are limiting in some contexts. Other studies have found that given this ambiguity there is no generally accepted definition of local food (Martinez et al. 2010).

In a formal food system, the previously mentioned eight components typically involve larger corporations, a considerable amount of administrative oversight and a highly organized, profit-maximizing approach to production and distribution. A large majority of the food most people in the United States eat comes from this type of formal source. Yet the formal food system has left considerable gaps for many segments of the U.S. population.

Food deserts, as defined by the U.S. Department of Agriculture, are areas devoid of fresh fruits, vegetables and generally healthy food options. Food deserts are often found in impoverished areas that lack access to farmers markets, grocery stores and other healthy food providers (Gallagher 2010). Alternative urban food systems attempt to accommodate for these gaps by offering food security, food proximity, food self-reliance and food sustainability. These efforts often create value (e.g., noncommodified mutual aid networks) that lies outside of, but supports in significant ways, the formal market economy. By encouraging local growth and consumption of produce, the alternative urban food system has the potential to fill in the gaps that the formal food system has created.

Alternative urban food systems, in particular community gardens, are designed to "enhance the environmental, economic, social and nutritional health of the residents within a particular place" (MarylandNational Capital Park and Planning Commission 2012). Usually they operate in the context of socially disadvantaged areas and marginal populations, and serve as alternative economic systems. In alternative food systems, the emphasis is on building community relationships in the food system that can enhance health, society and the environment. Communities have alternative food economies for different reasons: educating and promoting healthy practices, alleviating food insecurity, substituting store-bought food, fostering community building, rehabilitation training and therapy, 
(CSA) frequently provide cost savings (Cooley and Lass 1998; Park et al. 2011) and so too do community gardens. Studies have documented the frequency with which community gardeners cite the direct correlation between their community gardening and lower grocery bills (Blair et al. 1991; Patel 1991). However, little is known about the other means through which community gardening promotes economic benefits. The informal channels of barter and food exchange are of particular interest to our project because of the pervasiveness of the informal economy in low-income communities.

\section{Earlier survey, new survey}

This project builds on our previous research completed in 2013, when we collaborated with a community-based organization to analyze the informal economy in City Heights, one of San Diego's most ethnically, racially and linguistically diverse communities (Rabinowitz Bussell and Bliesner 2013). Our research identified a robust informal economy, characterized by a wide-scale reliance on cash transactions, which played a significant role for local consumers and producers. A survey of over 100 residents found that food-related transactions, such as buying and selling produce or prepared foods made at home, were a major factor in strategies local residents used to increase their household income or engage with the informal economy. The implication was that an alternative urban food system existed

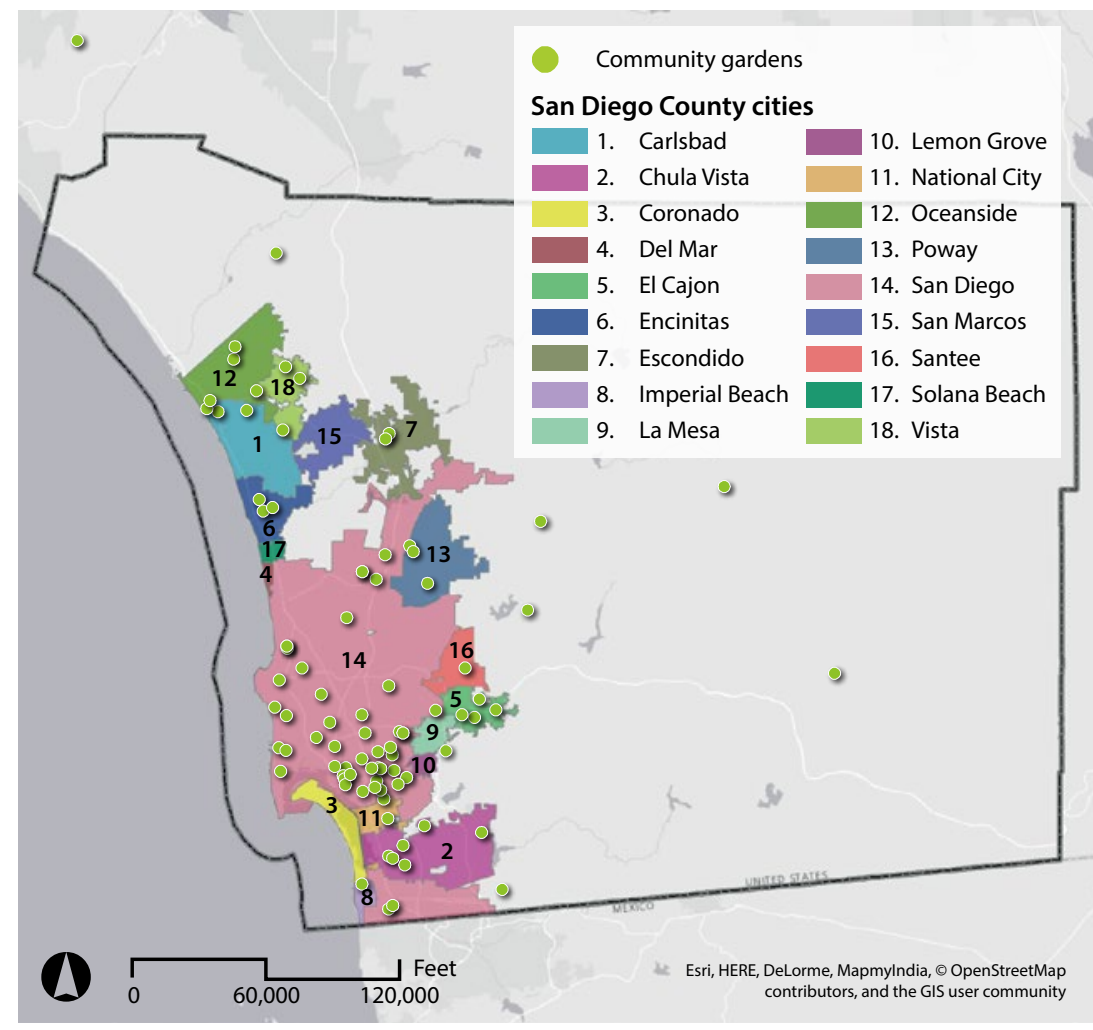

Fig. 1. The San Diego Community Garden Network. Map created by Arturo Tovar-Villalobos. and served as the primary source of this economic engagement.

Preliminary analysis showed that it could be effective to not only look at the structure and dynamics of the City Heights food system but to put it in the context of the larger countywide emerging alternative food system. We hypothesized that our findings were not unique to City Heights and that similar systems likely existed in other low-income, racially and ethnically diverse neighborhoods in San Diego.

With funding from the UC Global Food Initiative in 2015, we administered another survey, this time at eight different community garden sites throughout San Diego County. The survey (http://ucanr.edu/u. $\mathrm{cfm}$ ? id=177) was designed to better understand the reasons why people pursue community gardening and to discern whether low-income community gardeners are motivated by perceived or actual economic benefits. Toward this end, the survey collected data on the factors that draw people to community gardening, including social, well-being and economic reasons. The survey also included questions about the types and volume of produce commonly grown as well as other questions that sought to discern the adequacy of the community gardens in meeting the needs of their gardeners. Under our supervision, the survey was administered by a group of nine undergraduate students from the Urban Studies and Planning Program at UC San Diego, who received specialized training on survey design, administration and research protocols. Prior to commencing the research, the proposal was reviewed and approved by UC San Diego's Human Research Protections Program.

We created the survey and research design in close collaboration with the San Diego Community Garden Network (SDCGN). SDCGN supports community gardens with the larger goal of enhancing food security, promoting sustainability, and fostering social capital enhancement through community-based educational opportunities and community building. The network involves over 88 community gardens located throughout the region but primarily in urban areas, with a significant number located in low-income communities (fig. 1).

Its deep knowledge of San Diego's community garden ecosystem made it an ideal collaborator for this project as we sought to investigate a compelling research question within the framework of strengthening our capacity as a rooted university. The rooted university is one that invests a significant amount of attention and resources in place-based education, integrative research and community engagement. This approach is geared to understanding and improving how localglobal forces interact and shape the human-natural environments we inhabit (Pezzoli et al. 2014). It is further premised on the belief that it is possible for scholars to become engaged in civic matters and public scholarship in ways that add value and contribute substantively to 
academic discourse and at the same time yield benefits to civic life (Peters et al. 2003).

The survey was administered to 120 community gardeners at eight sites. The sites were strategically selected in consultation with the SDCGN based on several criteria. We sought to include sites that represented both socioeconomic and geographic diversity, with a primary emphasis on gardens in low-income communities. We included larger, more mature community gardens as well as younger and smaller gardens. As shown in figure 2, the sites included rural and urban locations, small and larger gardens, and represented in the final analysis a representatively diverse population.
Respondents ranged in age, with the majority, $76.6 \%$, between 30 and 79. They were ethnically diverse; $40 \%$ were Caucasian, $23.3 \%$ Hispanic or Latino, 6.7\% African-American, 7.5\% Asian, 6.7\% African, 5\% Middle Eastern and 5\% other ethnicities (fig. 3). The majority of the respondents were members of large households, with 51\% living in households of three or more people. Employment status was also diverse, and a relatively large percentage, $36.7 \%$, were retired. The majority of the respondents had relatively low levels of educational attainment; only $16.6 \%$ had completed a bachelor's or postgraduate degree, $45 \%$ had a high school degree but no further education.

\section{Community gardens surveyed}

\begin{tabular}{ll} 
Name & Calavera Schoolhouse Community Garden \\
Location & City of Carlsbad \\
Sponsor & City of Carlsbad \\
\# of garden plots & 28 \\
Waiting list status & N/A \\
\hline Name & City Heights Community Garden \\
Location & City Heights \\
Sponsor & Price Charities \\
\# of garden plots & 31 \\
Waiting list status & Long wait \\
\hline Name & City of Carlsbad, Harold E. Smerdu \\
& Community Garden \\
Location & City of Carlsbad \\
Sponsor & City of Carlsbad \\
\# of garden plots & 48 \\
Waiting list status & Long wait \\
Name & Linda Vista Community Garden at Bayside \\
Location & Linda Vista \\
Sponsor & Bayside Community Center \\
\# of garden plots & N/A \\
Waiting list status & N/A \\
\hline
\end{tabular}

Name

Location

Sponsor

\# of garden plots

Waiting list status

\section{Name}

Location

Sponsor

\# of garden plots

Waiting list status

\section{Name}

Location

Sponsor

\# of garden plots

Waiting list status

Name

Location

Sponsor

\# of garden plots

Waiting list status
Mosaic Community Garden of Chula Vista

City of Chula Vista

Gracia y Paz Covenant Church and the San

Diego Community Garden Network

$\mathrm{N} / \mathrm{A}$

$N / A$

\section{Mt Hope Community Garden}

Mt Hope (SE San Diego)

Project New Village

60

$\mathrm{N} / \mathrm{A}$

New Roots Fresh Farm Community Garden City of El Cajon

International Rescue Committee and Kaiser Permanente

45

$\mathrm{N} / \mathrm{A}$

Tijuana River Valley Community Garden Tijuana River Valley

Resource Conservation District 136

Long wait

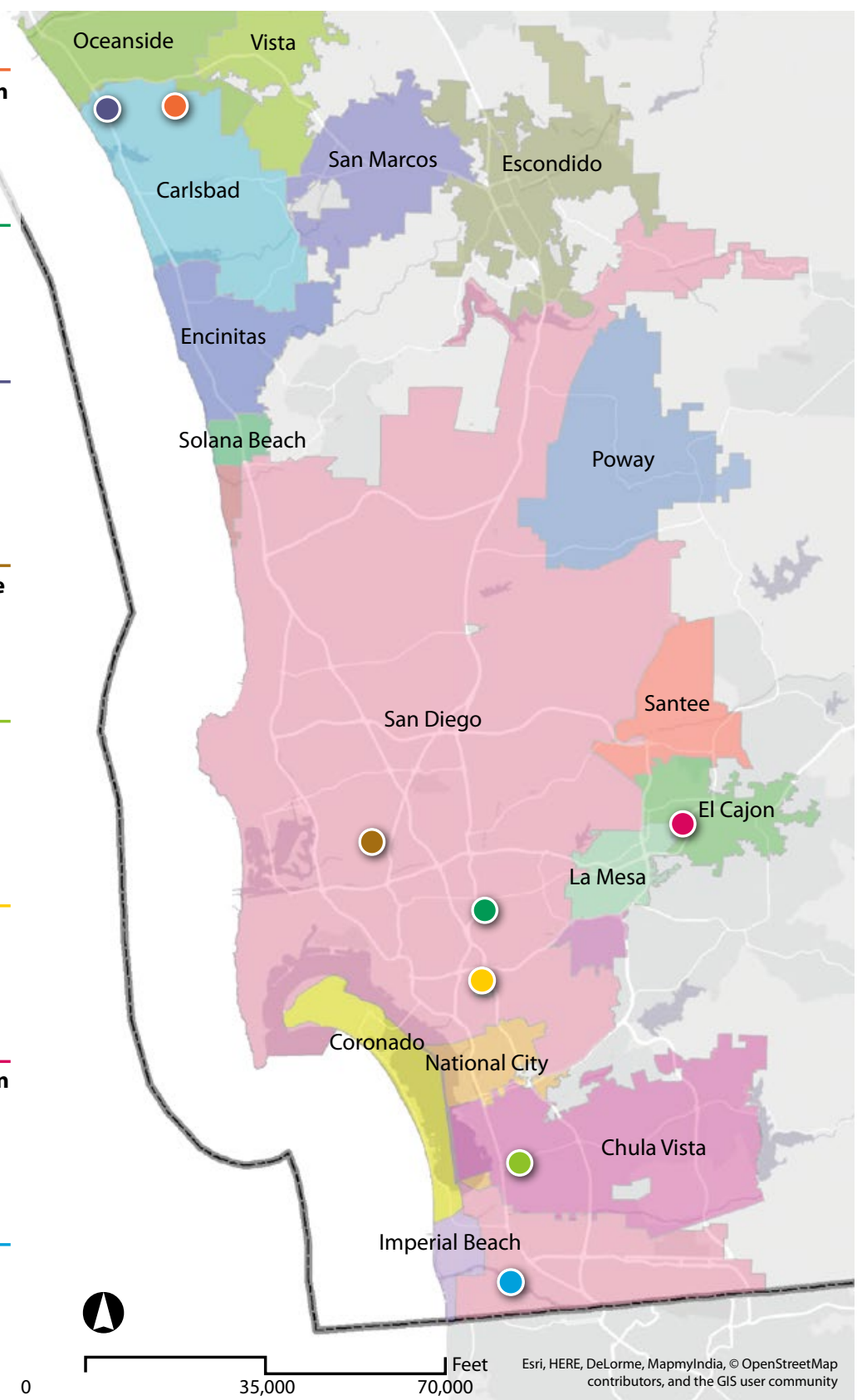

Fig. 2. Surveyed community gardens. Map created by Arturo Tovar-Villalobos. 


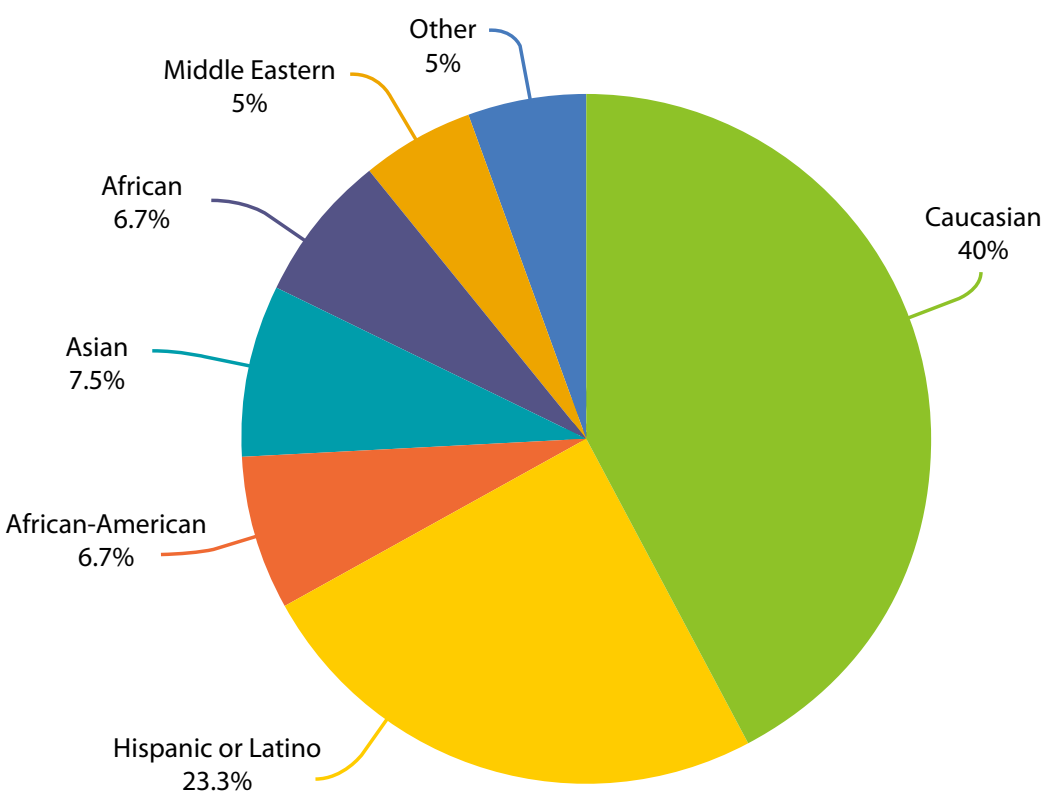

Fig. 3. Race and ethnicity of respondents.
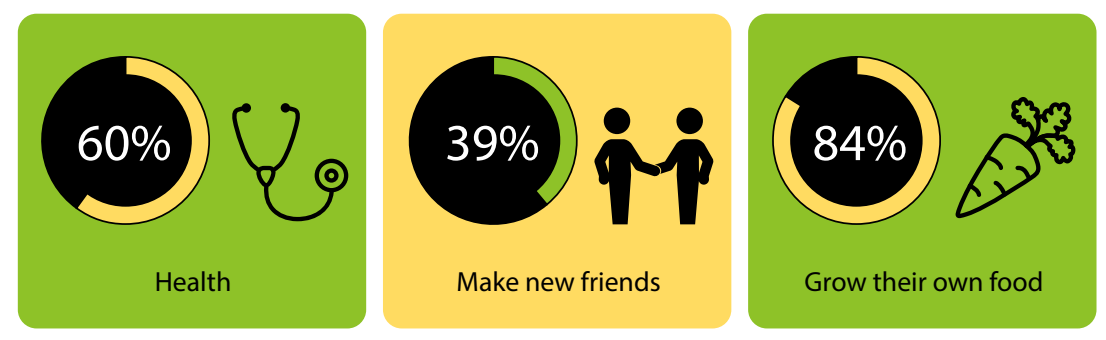

Fig. 4. Why people got involved with community gardens.

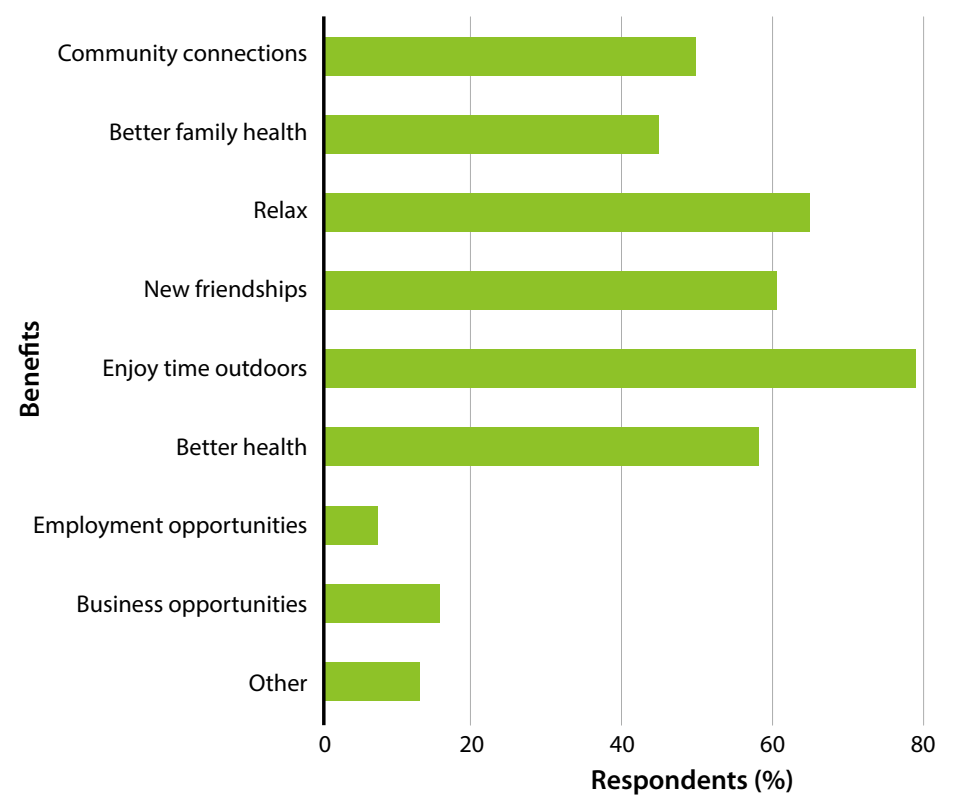

Fig. 5. Benefits of community gardens.

\section{Findings: many benefits}

The findings reveal that across a spatially and demographically diverse group of gardeners, there are many shared benefits and beliefs about the value of community gardens. Our findings validate the rich body of existing literature on urban agriculture that demonstrates the extent to which community gardens have the potential to serve at the nexus of social, economic and health empowerment in low-income communities. The data demonstrates that attitudes about health and well-being benefits are shared by almost everyone, yet as we discuss below attitudes about economic benefits are most pronounced in low-income communities.

\section{Health, well-being and social capital}

The survey results demonstrate the diverse motivations for community gardening, particularly as they relate to health and well-being. As shown in figure 4, in addition to the $84 \%$ of respondents who got involved with community gardening to grow their food, $60 \%$ of respondents were involved with community gardening to improve their health and $39 \%$ garden to make new friends.

With respect to broader perceived benefits of community gardening, figure 5 shows that $50 \%$ of the respondents believed that community connections are one of the benefits of belonging to a community garden. Furthermore, $61 \%$ had cultivated new friendships, $65 \%$ found community gardens relaxing and $79 \%$ enjoyed spending time outdoors. Furthermore, 90\% believed their household diet had improved because of growing their own produce and $90 \%$ confirmed that their household had eaten more fresh fruits and vegetables since they started to grow their own produce.

With just a few exceptions, most respondents (90\%) were first-time community gardeners. Many of them invested a considerable amount of time in their gardening activities; the survey found that $48 \%$ of respondents spent at least 5 hours each week at the garden. Respondents learned about the existence of their community garden from a variety of sources, including local organizations (20\%), friends (41\%) and family (12\%), which speaks to the informal and formal channels through which knowledge about urban agriculture is disseminated.

The findings also illustrate the significant relationship between community gardens and the built environment. Many respondents, $40 \%$, did not have space for their own garden. Furthermore, $88 \%$ believed that their neighborhood needed more community gardens; at least three of the gardens in the survey had waiting lists over 1 year long. This suggests an unmet demand for gardens and challenges with their spatial distribution. Furthermore, over one-third of the respondents, $35 \%$, belonged to a garden that was over 5 miles away from their home, and $26 \%$ of the respondents travelled 1 to 4 miles to reach their garden. For many people, distances greater than 1 mile can be problematic 


\section{In addition to the $84 \%$ of respondents who got involved with community gardening to grow their own food, $60 \%$ of respondents were involved with community gardening to improve their health and 39\% garden to make new friends.}

without adequate transportation options. Most gardeners, $63 \%$, used a car as their primary mode of transportation from their home to the garden; $23 \%$ walked, $6 \%$ biked and $5 \%$ took public transportation.

\section{Economic benefits}

This study was designed with an explicit focus on better understanding the economic benefits of community gardens. The findings suggest that the economic benefits have the potential to be most significant in lowerincome communities. Similar to findings from other research (Blair et al. 1991; Patel 1991), 78\% of respondents said that they saved money every month on their grocery bills. The majority, $68 \%$, said that they saved between $\$ 0$ to $\$ 39$ every month, and $10 \%$ said that they saved between $\$ 40$ and $\$ 60$. In addition to these direct impacts, the responses point to less quantifiable, but equally compelling, potential economic benefits.

As shown in figure 6, when asked what they do with their produce, the overwhelming majority of respondents (96\%) responded that they ate at least some of it at home and $26 \%$ drank some of it at home. Additionally, $55 \%$ gave produce to their extended family, $24 \%$ donated produce, $18 \%$ traded produce for other products and services and $64 \%$ gave produce to their friends. These networks of barter and donations have economic implications since the recipients of these items likely save money on their monthly food bills.

The survey found that $12.5 \%$ of respondents sold at least some of their produce to buyers. This statistic corroborates Armstrong's (2000) findings from her study of community gardens in upstate New York. Armstrong interviewed community garden managers to ascertain the reasons why people participate in community gardens, and she found that $10 \%$ of gardeners used the sale of their produce as an income supplement. This finding has several layers. Some community gardens have policies that prohibit or discourage the resale of produce grown on the site. One of the surveyed gardens is in a city in northern San Diego county that has municipal ordinances that are vague concerning gardeners' rights to sell their produce. After reviewing the city's municipal ordinances and community garden policies, we concluded gardeners' rights to sell were unclear, but the manager of the community garden shared with us her impression that gardening for retail use was prohibited.

Other gardens, however, encouraged their growers to use their plots as economic resources. For example, one surveyed garden is part of the International Rescue Committee's New Roots program, which provides community garden plots to new refugees, who use the sites for small business farming. The majority of gardeners surveyed at this site (84\%), designed to serve a very-low-income population, reported that they used the community garden to supplement their income. Of the gardeners there, $70 \%$ spent over 10 hours a week at the garden and $70 \%$ reported that their participation in the community garden had helped them to increase their household income. All of these gardeners also responded that they would like to increase the amount of produce that they are able to sell.

\section{Lessons, policy implications}

Our findings have implications at several scales, from the individual gardener and their household to the larger civic infrastructure. For the individual gardener, the survey identified the benefits of community gardens across a demographically and geographically diverse population. On a larger scale, we found that community gardens are a spatially based nexus of social and health empowerment in all communities. Socially, they are hubs for community building and connection. They are rich sites for interpersonal relations and informal knowledge exchange. The survey responses do not capture it, but as we spent several hours at each site during our research, we were struck by the camaraderie among the gardeners and between the gardeners and garden managers. From a health and well-being perspective, our survey showed that these gardens enhanced physical and mental health. They contribute to personal and community well-being and serve as valuable sites for promoting health and enhanced social networks.

The physical location of community gardens is also highly valued, and in fact demand frequently outstrips supply. The development of community gardens is

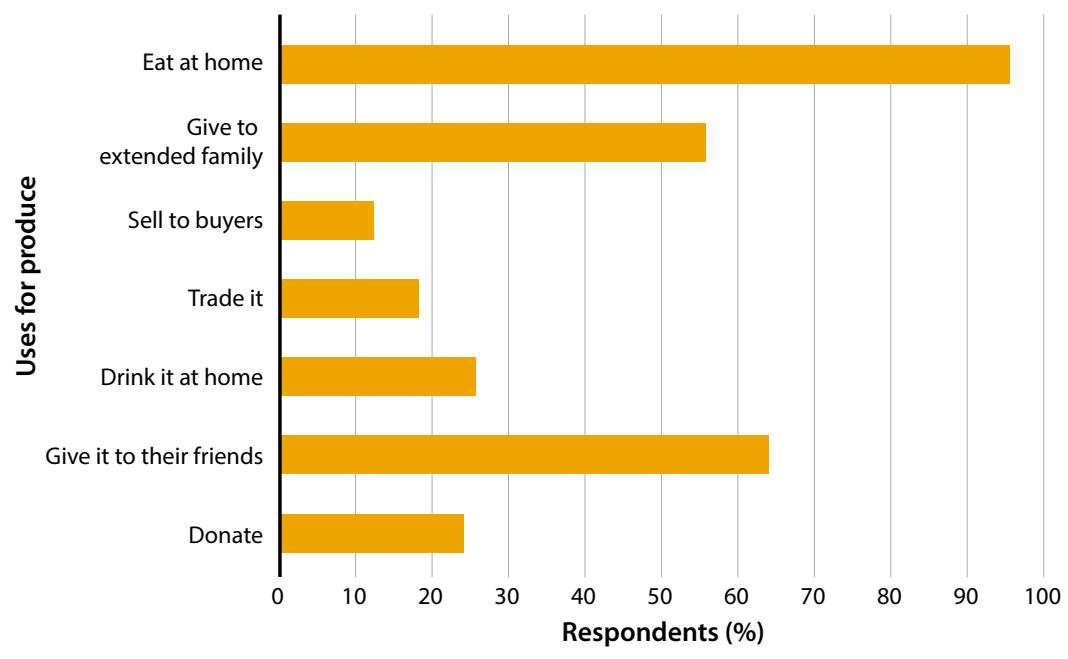

Fig. 6. Uses for produce grown at community gardens. 
Tijuana River Valley Community Garden, which has a long waiting list for plots, was one of eight sites studied. Of the 120 gardeners who responded to the survey, $55 \%$ said they gave produce to their extended family, and $18 \%$ traded produce for other products and services. beneficial from a land use perspective. The size of the sites is not necessarily important. Distance is critical, though, and to avoid transportation barriers gardens must be situated in close proximity to alternative forms of transportation.

Economically, we found preliminary evidence that community gardens have the potential to positively contribute to household and community wealth in low-income communities through both formal and informal mechanisms. Many gardeners were able to measure the economic benefits in terms of money saved or money from produce sales; however, of particular interest to us, given that this project derived from a previous study on the informal economy, was the presence of informal produce exchange networks. We found a potentially robust network of barter and donations among community gardeners, particularly lowincome ones, and their friends and families. With the presence of adequate support, training and local policies, these local gardeners may be able to successfully leverage untapped entrepreneurial capacity to directly sell their produce at farmers markets, produce stands or perhaps even local restaurants. Informal networks also may have the potential for further economic benefits by facilitating the bartering of unused produce for other goods and services or the donating of produce to friends and family to improve their health and reduce their food costs.

Following the work of Rogalsky (2010), who used ethnography and travel diaries to understand the spatial networks of low-income women, we propose that future research employ a similar approach to mapping out and quantifying informal produce exchange networks connected with community gardening activities.

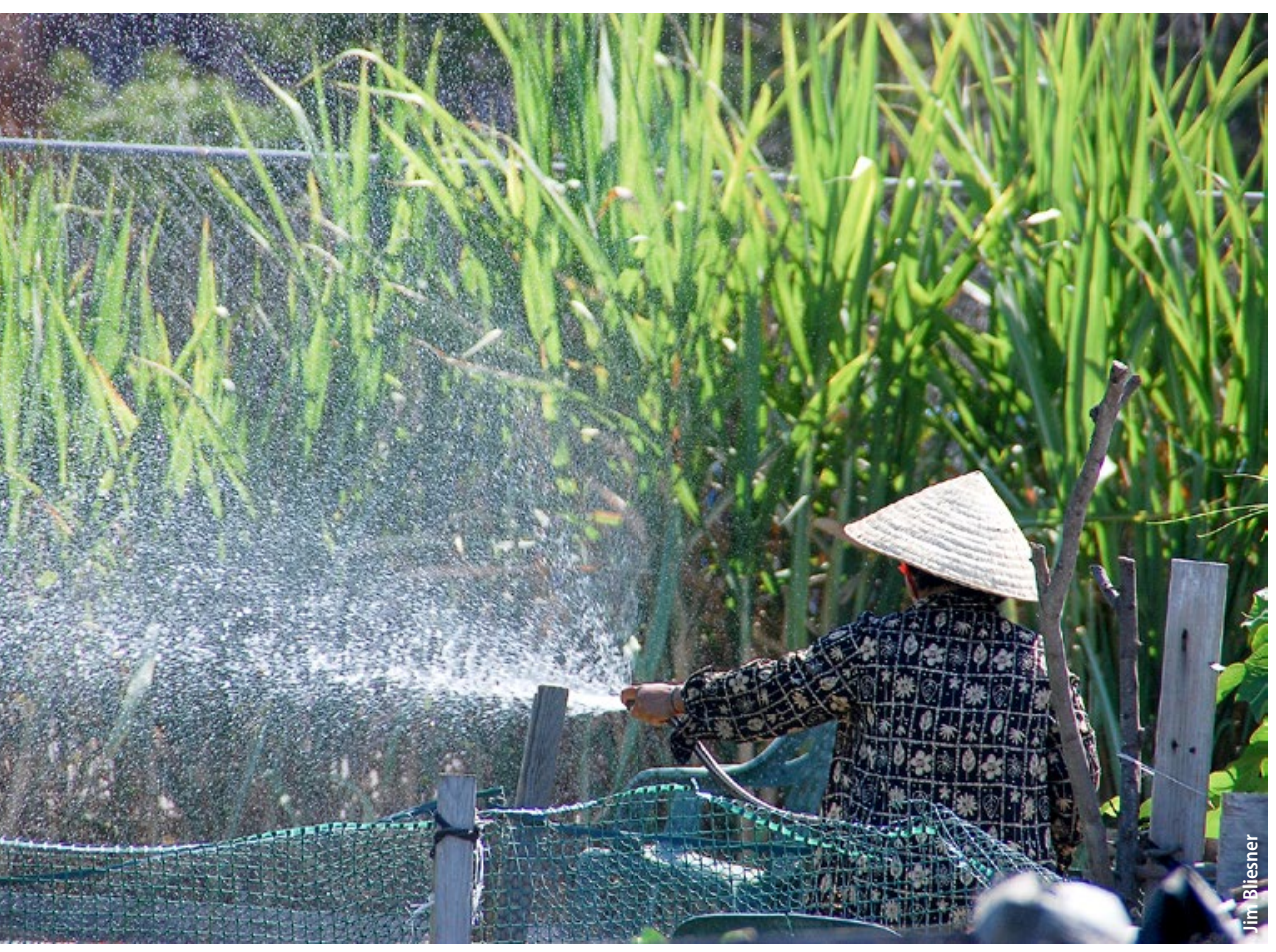

This would enhance our understanding of the economic impact, at all scales (both formal and informal), of community gardens.

At the policy level, fostering the growth of community gardens is enhanced when community groups work with state officials and municipalities. Current scholarship, also borne out in our research, has found that one of the biggest obstacles for small growers is access to land and capital. Therefore, we contend that by altering land use policy, cities can provide spaces for gardening on public lands, as well as ensuring the existence of consistent funding sources and simplifying bureaucratic requirements. California's new Urban Agriculture Incentive Zones Act (AB551), enacted in 2014, should help facilitate this because it was designed to increase land access for urban agriculture on vacant privately owned land.

Useful tools, such as the UC Division of Agriculture and Natural Resources Guide to Implementing the Urban Agriculture Incentive Zones Act (Zigas n.d.), should be widely disseminated. Furthermore, jurisdictions should be encouraged to permit the use of community gardens for small business farming. The International Rescue Committee's New Roots Program, for example, has experienced small-scale success and should be emulated. Efforts such as these would further enhance community garden contributions to community development.

\section{Institutional shift}

Universities are under increasing pressure to be socially accountable and to deliver knowledge and tools that prove useful in dealing with the 21st century's complex and costly problems. The UC Global Food Initiative supported this project in a way that encourages a rooted university transition - that is, a shift by our institutions of higher education and research to put more effort into problem-solving and solutions-oriented scholarship of engagement (in sync with basic science and discovery).

Our study underscores the merits of knowledgeaction collaboratives and the civic infrastructure that they create. As a community-university partnership, we and SDCGN codesigned the survey to ensure that the resulting data would be beneficial to SDCGN membership as a whole as well as the individual community gardens and their gardeners. At the same time, the project incorporated a classroom-based component. We created a new research class in the Urban Studies and Planning Program at UC San Diego to work in parallel with the project. This class enabled undergraduate students to participate in all facets of the project from community outreach to survey design and administration and data analysis.

We intend to continue our efforts to build these knowledge-action collaboratives since they offer the potential to yield substantive benefits to all participants. They require a significant investment of time 
and a dedication to nurture trust and relationships, but if patience is exercised the merits are as follows. For faculty researchers who subscribe to the merits of public scholarship, these collaboratives build university-community trust, deepen civic infrastructure and lead to other opportunities for engaged scholarship. For community partners, collaboratives such as these can elevate the visibility of local concerns and serve as a catalyst for dialogue, action and policy formulation. Finally, the pedagogical merits of such knowledgeaction collaboratives can be quite rich. They provide students with opportunities to apply classroom knowledge to real-world challenges, thereby deepening their understanding of complex issues while developing their skill sets and competencies. CA
M. Rabinowitz Bussell is Director of Field Research, Urban Studies and Planning Program, UC San Diego; J. Bliesner is Director, Center for Urban Economics and Design, and Lecturer, Urban Studies and Planning Program, UC San Diego; and K. Pezzoli is Director of Urban Studies and Planning Program and Bioregional Center for Sustainability Science, Planning and Design, and Professor, Department of Communication, UC San Diego.

This project received generous support from the UC GFI. Walt Sandford, Executive Director of the San Diego Community Garden Network, was a valuable community partner. Jacquelynne Lê played an equally important role as our Field Research Coordinator. Undergraduate students Cheryl Lim and Katie Persons were the lead student researchers and made significant contributions to the project. The following students also assisted with the project: Christina Baek, Payton Carrol, Erica Hong, Chanju Yang, Jeffrey Kung, Cynthia Wong and Naera Meza.

\section{References}

Armstrong D. 2000. A survey of community gardens in upstate New York: Implications for health promotion and community development. Health Place 6:319-27.

Blair D, Giesecke C, Sherman S. 1991. A dietary, social and economic evaluation of the Philadelphia Urban Gardening Project. J Nutr Educ 23:161-7. Bregendahl C, Flora CB. 2006 The Role of Collaborative Community Supported Agriculture: Lessons from lowa. North Central Regional Center for Rura Development, Ames, IA www.leopold.iastate.edu/files/ pubs-and-papers/2006-09-rolecollaborative-communitysupported-agriculture-lessons iowa.pd

Castells M, Portes A. 1989 World underneath: The origins, dynamics, and effects of the informal economy. In: Portes A, Castells M, Benton LA (eds.). The Informal Economy: Studies in Advanced and Less Developed Countries. Baltimore, MD: Johns Hopkins University Pr. p 11-37.

Cohen C, Sanghvi R. 2012. Five Borough Farm: Seeding the Future of Urban Agriculture in New York City. Design Trust for Public Space, New York City. http://designtrust.org/publications/five-borough-farm/.

Cooley JP, Lass DA. 1998 Consumer benefits from community supported agriculture membership. Rev Agric Econ 20:227-37.

Feenstra G, Lewis C. 1999. Farm-ers' markets offer new business opportunities for farmers. Calif Agr 53:25-9.

Ferguson RE, Dickens WT (eds.). 1999. Urban Problems and Community Development. Washington, D.C.: Brookings Institution $\mathrm{Pr}$.
Gallagher M. 2010. USDA defines food deserts. Nutr Digest 37:4. http://americannutritionassociation.org/newsletter/ usda-defines-food-deserts.

Garrett S, Feenstra G. 1999. Growing a Community Food System. Western Rural Develop ment Center, Pullman, WA.

Glover T, Shinew K, Parry D. 2005. Association, sociability, and civic culture: The democratic effect of community gardening. Leisure Sci 27:75-92.

Golden S. 2013. Urban Agriculture Impacts: Social, Health and Economic: A Literature Review. UC Sustainable Agriculture Research and Education Program Agricultural Sustainability Institute at UC Davis, Davis, CA. http://asi.ucdavis.edu/ programs/sarep/publications/ food-and-society/ualitreview-2013.pdf.

Hart K. 1973. Informal income opportunities and urban employment in Ghana. J Mod Afr Stud 11:61-89.

Hendrickson MK, Porth M. 2012. Urban Agriculture - Best Practices and Possibilities. University of Missouri Extension: Division of Applied Social Sciences. http://extension.missouri.edu/ foodsystems/documents/urbanagreport_072012.pdf.

Hicks E, Seidl A. 2008. Food, conservation, and energy ac of 2008: Environmental quality incentives program (EQIP). Colorado State University Extension Agricultural and Resource Policy Report 4:1-5. https:// dspace library.colostate.edu/ handle/10217/44796.
Hlubik WT, Hamm MW, Winokur MA, Baron MV. 1994. Incorporat ing research with community gardens: The New Brunswick Community Gardening and Nutrition Program. In: Francis M, Lindsey P, Rice JS (eds.). The Healing Dimensions of PeoplePlant Relations: Proceedings of a Research Symposium. UC Davis, CA: Center for Design Research, Department of Environmental Design. p 59-64.

Holland L. 2004. Diversity and connections in community gardens: A contribution to local sustainability. Local Environ 9:285-305.

Kaplan R. 1973. Some psychological benefits of gardening Environ Behav 5:145-61.

Kobayashi M, Tyson L, Abi-Nader J. 2010. The Activities and Impacts of Community Food Projects 2005-2009. p 1-28. https:// nesfp.org/sites/default/files/ uploads/activities_impacts_of_ cfps_2005-09.pdf.

Lillie-Blanton M, Hoffman SC. 1995. Conducting an assessment of health needs and resources in a racial/ethnic minority community. Health Serv Res 30:225-36.

Martinez S, Hand M, Da Pra M, et al. 2010. Local Food Systems: Concepts, Impacts, and Issues. ERR 97. US Department of

Agriculture Economic Research Service.

Maryland-National Capital Park and Planning Commission. 2012. Urban Agriculture: A Tool for Creating Economic Development and Healthy Communities in Prince George's County, MD. Prince George's County Planning Department, Prince George's County, MD.
McCormack LA, Laska MN, Larson NI, Story M. 2010. Review of the nutritional implications of farmers' markets and community gardens: A call for evaluation and research efforts. J Am Dietetic Assoc 110: 399-408.

Metcalf SS, Widener MJ. 2011 Growing Buffalo's capacity for local food: A systems framework for sustainable agriculture. Appl Geogr 31:1242-51.

Mount P. 2010. Comparing the structure, size, and performance of local and mainstream food supply chains. [Review of RP King, MS Hand, G. DiGiacomo, et al. Comparing the Structure, Size, and Performance of Local and Mainstream Food Supply Chains] J Agric Food Syst Community Dev 1:187-9. doi:10.5304/jafscd.2010.012.005.

O'Hara JK, Pirog R. 2013. Economic impacts of local food sys tems: Future research priorities. J Agr Food Syst Commun Dev 3:35-42. http://doi.org/10.5304/ jafscd.2013.034.003.

Park Y, Quinn J, Florez K, et al. 2011. Hispanic immigrant women's perspective on

healthy foods and the New York City retail food environment: $A$ mixed method study. Soc Sci Med 73:13-21

Patel, IC. 1991. Gardening's so cioeconomic impacts. J Extension 29:1-3.

Peters SJ, Jordan NR, Alter TR, Bridger JC. 2003. The craft of public scholarship in land-grant education. J High Educ Outreach Engage 8:75-86.

Pezzoli K, Kozo J, Ferran K, et al. 2014. One bioregion/onehealth: An integrative narrative for transboundary planning along the US-Mexico border. Glob Soc 28:419-40.
Rabinowitz Bussell M, Bliesner J. 2013. The Informal Economy in City Heights. City Heights Community Development Corporation, San Diego, CA www. cityheightscdc.org/wp-content/ uploads/The-Informal-Economy-in-City-Heights_FinalVersion_August-26-2013.pdf.

Rogalsky J. 2010. Bartering for basics: Using ethnography and travel diaries to understand spatial constraints and social networks among working poor women. Urban Geogr 31:1018-38.

RUAF Foundation. n.d. Urban Agriculture: What and Why? www.ruaf.org/urban-agriculture-what-and-why.

Saldivar-Tanaka L, Krasny ME. 2004. Culturing community development, neighborhood open space, and civic agriculture: The case of Latino community gardens in New York City. Agric Human Values 21:399-412.

Speer PW, Hughey J. 1995. Community organizing: An ecological route to empowerment and power. Am J Commun Psychol 23.729-48.

Teig E, Amulya J, Bardwell L, et al. 2009. Collective efficacy in Denver, Colorado: Strengthening neighborhoods and health through community gardens. Health Place 15:1115-22.

Travaline K, Hunold C. 2010. Urban agriculture and ecological citizenship in Philadelphia. Loca Environ 15:581-90.

Ulrich RS. 1981. Natural versus urban scenes, some psychophysiological effects. Environ Behav 13:523-56.

Zigas E. n.d. Guide to Implementing the Urban Agricultural Incentive Zones Act. University of California Division of Agriculture and Natural Resources. http://ucanr.edu/sites/UrbanAg/files/190763.pdf. 